\title{
Criollismo, experiencia popular y política: el gaucho como emblema subversivo
}

Adamovsky, Ezequiel

Universidad de Buenos Aires-Universidad Nacional de San Martín-CONICET, Argentina

e.adamovsky@gmail.com

Cita sugerida: Adamovsky, E.(2018). Criollismo, experiencia popular y política: el gaucho como emblema subversivo Anuario del Instituto de Historia Argentina, 18 (1), e067. https:// doi.org/10.24215/2314-257Xe067

Recibido: 27 Julio 2017 - Aceptado: 01 Febrero 2018 - Publicado: 28 de junio de 2018

(c) (1) (2) Esta obra está bajo licencia Creative Commons Atribución-NoComercial-CompartirIgual 4.0 Internacional (c) 1 BY $\mathrm{CA}$ iA $\mathrm{http}: / /$ creativecommons.org/licenses/by-nc-sa/4.0/deed.es_AR 


\title{
Criollismo, experiencia popular y política: el gaucho como emblema subversivo
}

Criollismo, lower-class experience and politics: the gaucho as a subversive emblem

\author{
Ezequiel Adamovsky \\ Universidad de Buenos Aires-Universidad Nacional de San \\ Martin-CONICET, Argentina \\ e.adamovsky@gmail.com
}

\begin{abstract}
Resumen:
El presente trabajo pone en discusión la interpretación del fenómeno del “criollismo popular” en Argentina como una expresión pasajera y propia de las tensiones y desacoples de un proceso de “modernización”. Por el contrario, a partir del análisis de la literatura barata de circulación entre las clases populares, de las canciones de los payadores criollos y del teatro de temática gauchesca se sostiene aquí que debe considerárselo un fenómeno más perdurable, cuya función fue más bien la de canalizar críticas sociales -a las élites dirigentes, de clase y étnico-raciales-y la de colaborar con el proceso de "etnogénesis", es decir, de la conflictiva definición de un sentido de distintividad grupal a partir de la heterogénea población que ocupaba el territorio argentino hacia finales del siglo XIX.
\end{abstract}

Palabras ClaVE: Criollismo, Etnogénesis, Argentina, Gaucho.

\begin{abstract}
:
This paper argues against the usual interpretation of the phenomenon of "popular criollismo" in Argentina as a short-lived expression of the tensions and conflicts brought about by a process of "modernization". By analyzing gaucho dime novels, the songs of the payadores and gauchesque theatre plays, it is argued that "popular criollismo" should be considered instead as a more perdurable phenomenon that served to channel social criticism against the ruling elites, class differences and ethnic-racial hierarchies. More importantly, it also played a major role in the process of ethnogenesis, i. e., the definition of a sense of group distinctivity among the heterogeneous multitude that inhabited the Argentinean land in the late 19th century.
\end{abstract}

KeYwords: Criollismo, Ethnogenesis, Argentina, Gaucho.

El fenómeno del "criollismo popular" que surgió con fuerza imparable en el área del Río de la Plata en el último tercio del siglo XIX tendió a ser analizado como una reacción pasajera frente a las tensiones de la rápida urbanización, la llegada masiva de inmigrantes y otros cambios en las costumbres. Según esta visión, propuesta por Adolfo Prieto (2006), se habría agotado luego de 1920, una vez que el supuesto proceso de "modernización” estaba concluido. La perdurabilidad posterior de las evocaciones del mundo gauchesco tendieron a explicarse sobre todo por el hecho de que fueron adoptadas por el Estado y por ciertos grupos políticos e intelectuales, que las utilizaron para impulsar ideas nacionalistas de corte más bien derechista y autoritario (por ej., Casas, 2017). En otro sitio he mostrado que la idea de una extinción súbita en 1920 no se sostiene en la evidencia empírica, que sugiere, en cambio, que siguió siendo un fenómeno masivo y genuinamente popular hasta, al menos, fines de los años cuarenta (Adamovsky, en prensa). En este trabajo me propongo avanzar en una explicación alternativa de la pregnancia del criollismo popular, apoyada sobre todo en un análisis de los modos en los que conectaba con la experiencia de las clases subalternas -el antagonismo respecto de las élites gobernantes, las tensiones de clase y étnicas, la construcción de sentidos de masculinidad- y las maneras en las que colaboró en un imprescindible proceso de etnogénesis. Como veremos, lejos de vincularse indefectiblemente con visiones políticas derechistas, en la primera mitad del siglo $\mathrm{XX}$ fue con frecuencia canal para políticas progresistas, incluso de izquierda y revolucionarias. 
El corpus documental analizado aquí es el del "criollismo popular", definido como el conjunto de producciones culturales que tematizan la vida de las clases populares presentes o pasadas a partir de alusiones a la figura del gaucho. De ese conjunto, el de tipo "popular" se restringe a aquel que fue producido por artistas o escritores de origen popular, o con intención de llegar a un público de clases bajas, o que circuló de manera masiva sin depender de impulsos estatales (cualquiera hubiera sido el origen social o la intención inicial de su autor). Los soportes, géneros y canales de circulación de la variante popular del criollismo fueron variados: recitados orales y cantos populares, impresos baratos (novelas por entregas, folletos, hojas sueltas, cancioneros, refraneros, revistas, etc.), representaciones en el circo y en el teatro, actividades de los "centros criollos", disfraces y actuaciones en los carnavales, historietas, grabaciones, emisiones radiales, filmes e imágenes impresas. Su núcleo principal de producción fueron las ciudades de Buenos Aires y Rosario, pero consiguió irradiarse por todo el país (Adamovsky, en prensa). El recorte temporal de esta indagación abarca desde el surgimiento del fenómeno en su faceta masiva en la década de 1870 hasta las vísperas del peronismo, momento en el cual el género experimentará un nuevo proceso de politización que introducirá diferencias específicas, imposibles de sintetizar en un solo trabajo.

\section{EL CRIOLLISMO COMO CRítiCA SOCIAL: LAS CRíTICAS A LA LEY, A LA POSTERGACIÓN DEL CRIOLLO Y A LOS RICOS}

Desde el comienzo del fenómeno (incluso antes, en la tradición de la poesía gauchesca anterior), el criollismo popular utilizó la voz del gaucho para plantear una mirada crítica respecto del gobierno y sus funcionarios, junto con la sospecha de que las leyes en verdad estaban reñidas con la verdadera justicia. Como es bien sabido, el Martín Fierro se compone de dos partes, publicadas con algunos años de diferencia, cuya orientación es francamente disímil. En la primera, aparecida en 1872, la crítica es amarga y desesperanzada, mientras que la segunda, de 1879, invita a la reconciliación con la sociedad. Así y todo, en ambas partes los reproches a la ley y a la autoridad son explícitos y muy visibles. Jueces y militares son objeto de numerosas críticas, por el maltrato a los soldados y la injusticia de las levas, por su corrupción, por los negociados que hacían con los fondos públicos, por la manipulación de las elecciones para favorecer a determinados candidatos. Pero lo más importante es que las críticas se convierten en el poema en sentencias de valor abstracto en las que, además, gaucho y pobre se vuelven términos intercambiables:

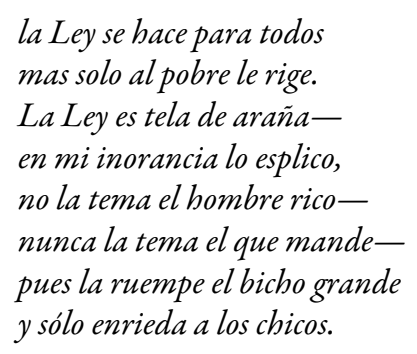

El Juan Moreira de Eduardo Gutiérrez también contiene críticas a las levas, a los abusos de las autoridades de campaña y al "estado de criminal abandono" en el que viven los gauchos, "privados de todos los derechos". El principal enemigo del héroe, de hecho, es el teniente alcalde que pretende a su mujer y que, abusando de su autoridad, lo empuja a "desgraciarse". El enfrentamiento con las autoridades y los policías asume en el Moreira el carácter explícito de un choque de legalidades: el gaucho se hace matrero tras comprobar que, para él, "no había más derecho que el que le proporcionara el filo de su puñal". Cuando mate lo hará, según él, peleando como un valiente y "en buena ley" (Gutiérrez, 1961, pp. 19-20, 25, 61; tb Gutiérrez 1880, p. 4).

Este tipo de contenido es absolutamente dominante en el criollismo popular de las siguientes seis décadas. Prácticamente no hay historia de matreros en la que alguna injusticia de un oficial del Estado no intervenga 
a la hora de explicar el camino de violencia emprendido por el héroe. Los enemigos de la libertad del gaucho son casi siempre policías, militares, jueces. La voz gauchesca también siguió habilitando críticas en las que la ley aparecía como un aparato de opresión de los pobres. Un popular payador del cambio de siglo, por ejemplo, cantaba:

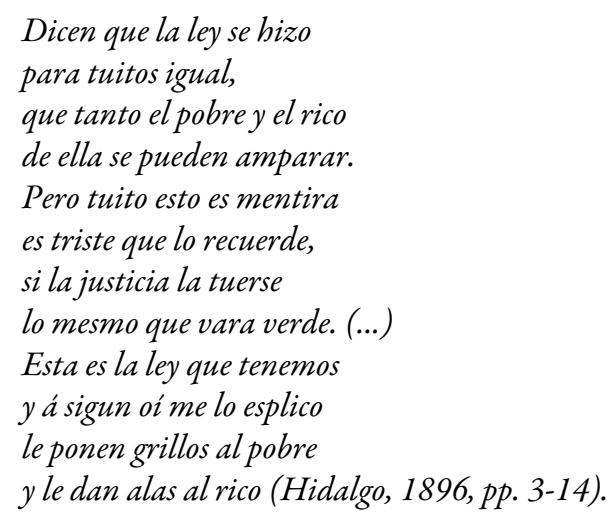

En el criollismo, las críticas a la autoridad con frecuencia se entrelazaron con manifestaciones de hostilidad hacia los inmigrantes y con la afirmación de que los criollos habían sido injustamente postergados para beneficiarlos. El Martín Fierro (especialmente su primera parte) tiene varios pasajes de marcada hostilidad hacia los "gringos" y reprocha al gobierno "tirar la plata a miles" para ayudarlos, mientras se mantiene "al pobre soldao" en la pobreza total. El Juan Moreira de Gutiérrez también denuncia que el gaucho ha sido convertido en "paria en su propia tierra" y que los hacendados prefieren contratar extranjeros antes que criollos. El texto no contiene ataques a los inmigrantes comparables a los del poema de Hernández, pero de todos modos aparecen contrapuestos a la figura del gaucho a través del personaje del gringo Sardetti, el almacenero que estafa a Moreira en complicidad con el teniente alcalde y cuyo asesinato "desgracia" al protagonista (Gutiérrez, 1961, pp. 20 y 33).

En el criollismo popular posterior la crítica al gringo y el lamento por la postergación del gaucho son amargamente explícitos e insistentes. Una milonga de 1896 del payador Félix Hidalgo sintetiza bien la gama de reproches que solía lanzarse al "gringaje": les pagan el pasaje con dineros públicos; se quedan con los empleos y "al criollo lo echan a un lao"; están dispuestos a trabajar "por un mezquino jornal"; algunos "emprienden la industria" y se enriquecen rápidamente; otros se benefician del acceso a la tierra y las herramientas para trabajarla, "que el gobierno les ofrece" a ellos pero no a "nosotros los criollos". Incluso se involucran en política y se convierten en "grandes señores" y ocupan altos cargos. Peor aun, mientras el gringo prospera, al criollo lo obligan al servicio militar para proteger, como soldado, "la vida y los intereses/ de esos mismos estrangeros" (Hidalgo, 1896, pp. 3-14). En las décadas siguientes, por todas partes los folletos y revistas criollistas canalizaron reproches similares hasta volverlos un lugar común ${ }^{1}$. Conviene destacar, en este sentido, que en general apuntaron a la postergación social del pobrerío criollo y no giraron en torno de la xenofobia más típica de los intelectuales nacionalistas, cuya preocupación fundamental era la de la descaracterización nacional por la introducción de formas culturales importadas. En la literatura del criollismo popular esa temática sólo aparece tardíamente, desde los años treinta, en unos pocos textos que repudiaron que se estuviera "agringando" la cultura y corrompiendo el idioma (Aprile, 1934; Sierra, s/f, pp. 58-59).

La crítica al predominio de los gringos y el reclamo de igualdad ante la ley con frecuencia se deslizaron hacia una crítica de las diferencias de clase y de los efectos opresivos del capitalismo (algo facilitado por la sinonimia planteada entre gaucho y pobre). En el Martín Fierro, salvo alguna al pasar, los estancieros están sin embargo conspicuamente ausentes de las críticas. La relación entre el gaucho trabajador y su patrón está pintada allí de manera casi idílica, lo que delata la pertenencia de clase de Hernández y sus ideas políticas, 
orientadas a la defensa de los productores rurales. Así y todo, la primera parte del poema podía fácilmente ser leída también como una crítica al capitalismo (como lo fue, según veremos enseguida). Las nostalgias por un pasado de abundancia y la descripción de los padecimientos presentes del "pobre" terminaban en la resolución de Fierro de escapar de la sociedad hacia las tolderías indias, imaginadas como espacio de libertad, no sólo frente al Estado sino también frente al trabajo: "allá no hay que trabajar/ vive uno como un señor". En cambio, el protagonista de Solané (1872) -posiblemente la primera pieza teatral protagonizada por un gaucho alzado contra la autoridad- sí dirige duras palabras contra "la aristocracia del dinero y de la política"; para él la "espada" y el "capital" son las "dos mandíbulas del monstruo" que destruye a los gauchos (Fernández, 1924, pp. 307 y 341 ).

El Juan Moreira de Gutiérrez no presenta críticas a los hacendados o a los ricos en particular. Sin embargo, su Pastor Luna(1886) sí incluye al comienzo una larga descripción de los cambios económicos que estaban acorralando a los gauchos. Gutiérrez anota allí que la llegada del ferrocarril estaba acabando con los trabajos de peón de galeras, que las innovaciones técnicas en los establecimientos rurales -especialmente la introducción de los alambrados- ahorraban personal, que la suba del precio de los arrendamientos le quitaba a los gauchos puesteros la posibilidad de mantener ganado propio. Pero, sobre todo, la obligación de entregarse al "trabajo productivo" estaba modificando hondamente las costumbres del hombre de campo, que ya no encontraba tiempo para tocar la guitarra ni para divertirse en las pulperías (Gutiérrez, s/f, pp. 5-7). En el criollismo popular posterior este tipo de visiones será muy frecuente. El avance de la racionalidad económica capitalista se imagina habitualmente como una fuerza que le quita al gaucho su libertad y su conexión con la música y con la poesía. En particular el tópico del avance del alambrado que lo acorrala se reencuentra una y otra vez. En este punto podían coincidir también los tradicionalistas más conservadores, que lamentaban no tanto la opresión de clase como el ocaso del espíritu romántico de la tierra (por ej., Abaca, s/f, pp. 9-10; Fray Mocho, 1910, p. 26).

Pero el criollismo popular introdujo también críticas más explícitas y antagonistas. Aunque era muy infrecuente, en alguna de las historias de matreros el enemigo principal no era un funcionario estatal sino un "estanciero perverso" (Manco, 1943). En otras, no se escatimaban críticas a los "jailaifes" y "cagetillas". En una de 1899, por caso, el gaucho que habla los trata de holgazanes, explotadores, cobardes y vanidosos:

Los que tratan de borricos
a los pobres proletarios,
son seres estrafalarios
más estúpidos que micos.
Validos de que son ricos
y de sus trajes flamantes,
esos hombres inflamantes
siembran el social desquicio,
y buscan el precipicio
en que caerán por tunantes (López Franco, 1899, pp. 18-21) ${ }^{2}$.

\section{Criollismo y EXPERIENCIA POPULAR}

Más que con la necesidad de afirmar un sentimiento nacionalista y la lealtad a las élites dirigentes, el criollismo popular conectaba políticamente con la experiencia popular en un momento de grandes tensiones sociales. Y lo hacía en más de un modo.

Para empezar, expresaba bien los padecimientos de la población rural. Los historiadores han puesto en duda que hayan existido verdaderamente en el siglo XIX esos gauchos de vida errante que describía la literatura. Hay que decir sin desmedro de ello que, más allá de sus usos literarios, durante el siglo XIX el término gaucho había pasado a designar a los paisanos del campo genéricamente. Independientemente de la existencia o no 
del tipo gaucho o de su peso social, es indudable que las historias que se contaban oralmente o se leían en los textos criollistas tenían resonancias claras con la experiencia de vida de los paisanos pobres de entonces. No hay dudas de que, en el cambio de siglo, muchos enfrentaban padecimientos y desafíos análogos a los que tematizaban los textos de difusión popular. Los dramas gauchescos les ayudaban a dar sentido a los cambios dramáticos que venían afectando su mundo.

Los estudios sobre la vida en la campaña bonaerense muestran que el Martín Fierro describía la penosa realidad de los paisanos de un modo bastante preciso. Especialmente para los no propietarios la situación venía empeorando de manera sostenida luego de 1856. Los éxitos militares de los indígenas habían quitado amplias zonas del control de los blancos. Desde 1860 el Estado renovó sus esfuerzos para recuperarlas, por lo cual dio mayor poder y autonomía a los jueces de paz para que intensificaran la persecución a supuestos "vagos" como modo de proveerse de tropa para los fortines. La vida en la frontera era durísima y los penados rara vez conseguían volver, como no fuera desertando y arriesgándose por ello a ser fusilados. Buscar refugio entre los indios era una posibilidad que no pocos aprovecharon. En todo esto el Martín Fierro y el Juan Moreira eran más que realistas. También en la descripción de la manipulación de las elecciones por parte de los jueces locales, sobre la que abunda la documentación de la época.

Para los pequeños y medianos productores -labradores o pastores, que eran la mayoría de la población rural- la situación también venía empeorando. Aunque no tanto como los no propietarios, también ellos podían ser víctimas de las arbitrariedades de la autoridad. Pero además, su independencia económica venía en franco deterioro por el alza del precio de la tierra y su concentración creciente. A eso hay que sumar que la expansión del alambrado -lentamente antes de 1875, febrilmente luego- y el perfeccionamiento de las leyes y de las prácticas estatales tendientes a la protección del derecho de propiedad hicieron que, hacia 1880, los habitantes del campo perdieran libertades. El libre movimiento, el libre uso de lotes de tierra, el acceso al agua y a pasturas para el ganado, la posibilidad de cazar animales o de recoger leña y paja en los montes, todo ello se vio severamente limitado.

Finalmente estaba el tema de los inmigrantes. Desde la década de 1860 efectivamente llegaron al campo en una formidable oleada. Para fines de esa década, en algunos pueblos rurales ya eran la quinta o cuarta parte de la población. Fueron ellos los que tendieron a beneficiarse de las mejores oportunidades laborales, especialmente de la agricultura cerealera, que pronto experimentaría un boom. En ese contexto hubo un sentimiento, extendido entre los criollos, de haber sido postergados por su propio Estado. Ya que, entre otros beneficios, se eximía a los recién llegados de prestar servicio militar, muchos paisanos sentían que los mandaban a la frontera para proteger tierras que, al final, iban a ir para los gringos. Ese sentimiento motivó algo de xenofobia y tensiones reales entre unos y otros. En general fueron de baja intensidad, aunque hubo algunas que dieron lugar a violencias mayores. Entre éstas, la masacre de gringos a manos de una banda de gauchos ocurrida en Tandil en 1872 (de la que trata Solané, la obra de Fernández) (Garavaglia, 2001; Slatta, 1985, pp. 292-303).

Por todo esto, las visiones nostálgicas y las críticas que planteaba la literatura del criollismo popular estaban lejos de ser un mero invento de escritores urbanos: conectaban bien con la experiencia y con las percepciones de los paisanos que fueron sus primeros lectores. $Y$ aunque los cambios en años posteriores fueron dramáticos, la nostalgia por tiempos pasados no tenía por qué desaparecer junto con ellos. Si nos paramos imaginariamente en algún paraje bonaerense de 1925, encontraremos allí, ya ancianos, a algunos de los

Hay que destacar, de cualquier modo, que en la experiencia popular había por entonces enormes variaciones regionales. Incluso dentro del Litoral, los procesos descritos se dieron en momentos diferentes en distintas zonas. Lo que era una realidad para unos en 1880 -por caso el alambrado o el contacto con los inmigrantes- para otros llegó treinta años más tarde. A nivel nacional las variaciones eran incluso mayores. A propósito, si para un habitante bonaerense del cambio de siglo, personajes como Fierro o Moreira podían parecer propios de tiempos irremediablemente idos, eso no necesariamente era el caso para los de otras zonas. 
En Corrientes, por ejemplo, la vida de Olegario Álvarez - que parecía calcada de la de Moreira- dio lugar, a comienzos del siglo XX, a una leyenda popular de que perdura hasta hoy (Blanco, 2010). En otras partes del país e incluso más tardíamente otros bandidos rurales descritos como gauchos también se ganaron la admiración popular y generaron leyendas similares (Chumbita, 2011). Así, de diversas maneras, las historias de gauchos servían para procesar una experiencia de cambio social y para canalizar una visión crítica sobre el curso de la historia. Todavía en años recientes podían encontrarse ancianos criollos que recurrían a la poesía gauchesca con ese fin, como el antiguo tropero que una antropóloga entrevistó en Entre Ríos, escasamente alfabetizado, cuyos versos -dictados a su hija y autopublicados en 1999- hablaban de las penurias de los pobres, de las injusticias de funcionarios, ricos y patrones, y de las relaciones con la "gringada" que había llegado a sus pagos poco antes de que él naciera (Frontera, 1999; Freidenberg, 2013, p. 104).

Pero el atractivo del criollismo popular fue igualmente poderoso entre las clases trabajadoras urbanas, cuya realidad era bien diferente. Por supuesto, había también allí gente que había crecido en el campo. En la segunda mitad

del siglo XIX y durante buena parte del siguiente las principales ciudades de la región pampeana recibieron un importante contingente de migrantes internos procedentes de zonas rurales. Buenos Aires hospedó una gran cantidad, al principio llegados especialmente del interior bonaerense y del litoral, y desde los años treinta también de más lejos. Un viajero español tuvo la ocasión de hablar con uno de ellos en tiempos del Centenario. Mientras viajaba en tren interiorizándose de la literatura nacional con una copia del Martín Fierro en mano, un anciano con vestimenta urbana se le acercó. Le dijo que de joven había sido un gaucho, que vestía chiripá y galopaba libre por las llanuras, antes de que las estropearan los gringos con sus arados y sus máquinas para sacarle ganancias para ellos y para los estancieros. Y continuó con los ojos llenos de lágrimas viendo el campo por las ventanas:

Esto, de aquí a... yo no lo veré, no será un desierto ni una llanura, será... una mesa parada, con el estanciero a la cabecera, los peones gringos alrededor, y a nosotros, los gauchos que queden, nos tirarán las migas. Y si no, mire ipucha! Vaya mirando... Esto ya no es nuestra tierra... es... una fábrica de trigo... para enviarla a la gringuería. ¡Los gauchos a morir! (Rusiñol, 1911, pp. 209-212).

Sumadas las memorias rurales como las de este paisano al desarraigo y a la experiencia de vivir en ciudades tan caóticas y cosmopolitas como lo eran las de entonces, no cuesta demasiado explicar que este tipo de población tuviera motivos para sentir nostalgias por el mundo gaucho.

Por otra parte, también en las ciudades, los criollos (con o sin pasado rural) tenían buenos motivos para sentirse postergados frente a los inmigrantes. El aluvión que había llegado del exterior fue particularmente intenso en ciudades como Buenos Aires y Rosario, epicentros del criollismo popular. A comienzos de siglo la mitad de los habitantes de la primera eran extranjeros. Más aún, las oportunidades que el crecimiento económico abrió luego de 1870 quedaron en buena medida en manos de extranjeros, que pasaron a dominar el comercio y la industria, y adquirieron preponderancia en otras áreas. Las estadísticas muestran, además, que un gringo de clase baja tenía muchas más chances de ascender socialmente que un criollo. En su célebre informe de 1904, Juan Bialet Massé señaló que había encontrado entre empleadores de diversas regiones del país un fuerte prejuicio según el cual los criollos eran peores trabajadores que los inmigrantes, lo que generaba acceso desigual a oportunidades para unos y otros (Bialet Masse, 1986). En ese contexto, no cuesta entender que la glorificación del pasado criollo y la crítica a los gringos que ofrecía el criollismo popular resultase atractiva, nuevamente, como modo de reclamar precedencia y de procesar tensiones sociales.

Más allá de las diferencias étnicas, el criollismo popular también servía para tramitar las diferencias de clase y la experiencia de exclusión política que compartían todos los que no pertenecían a las élites. Entre 1880 y las primeras elecciones limpias, en 1916, el sistema político argentino sufrió una relativa clausura por parte de los conservadores, que se mantuvieron en el poder mediante el fraude. Ello motivó el surgimiento de la Unión Cívica Radical, que promovió tres levantamientos armados contra el régimen conservador. El golpe de Estado de 1930 clausuró nuevamente la breve experiencia democrática hasta las elecciones de 1946. 
$\mathrm{Al}$ mismo tiempo, el acelerado crecimiento económico que se produjo entre aquellas mismas fechas se dio de un modo tal que favoreció la concentración de la riqueza. La brecha que separaba a ricos y pobres aumentó dramáticamente. Para 1910 la sociedad argentina era más desigual que nunca. La clausura política y la mayor desigualdad impulsaron a los trabajadores urbanos a organizarse. A partir de comienzos de la década de 1880 se extendieron rápidamente los sindicatos y el movimiento huelguístico. El movimiento obrero consiguió consolidarse con los anarquistas en clara hegemonía al menos hasta 1910; hegemonía compartida, más tarde, con sindicalistas revolucionarios, socialistas y luego comunistas. El Estado respondió a la insurgencia obrera con represiones sangrientas.

Así, en estos años la impresión de estar gobernados por una oligarquía que ponía al Estado al servicio de su clase no se alejaba demasiado de la realidad. Puede que los habitantes de las ciudades no tuviesen que padecer el tipo de abusos que sufrían los paisanos del campo, pero sí tenían excelentes motivos para identificarse con héroes populares que rechazaban a las autoridades y a las leyes, cuchillo en mano, por ser esencialmente injustas y antipopulares. Y, como poder político y jerarquías de clase realmente se solapaban, tampoco debe extrañar que la legalidad estatal, las oligarquías y el mundo de los ricos se confundiesen en un mismo rechazo, que encontraba en el gaucho perseguido un ícono atractivo. La propia literatura criollista hacía lugar a diatribas contra "cajetillas" y "jailaifes”, figuras que remiten a los ricos del ámbito urbano.

El sentido de antagonismo de clase del criollismo popular no pasaba inadvertido para las élites de entonces. En 1902 Ernesto Quesada anotó lo que para él era el motivo fundamental de su "popularidad asombrosa”:

Todos los que viven en pugna con la sociedad, desde el ladrón hasta el desterrado de la fortuna; desde el bandido hasta el atorrante; desde el que odia el oropel de los ricos, convencido de que jamás podrá alcanzar a gozar de él, hasta el que lucha descorazonado con la miseria y odia instintivamente a los que tienen medios de fortuna; todos los fermentos malsanos de la sociedad experimentaron verdadera fruición al leer las hazañas de esos matreros -verdaderos outlaws, enemigos del orden social- que acuchillaban policías... (Quesada, 1902, pp. 35-36)

Además de su potencial para la crítica social, las historias de matreros, con su culto al coraje, al honor y a la violencia, también servían a los varones para afirmarse en un modelo tradicional de masculinidad, algo especialmente apreciado a medida que las mujeres comenzaron a reclamar mayor independencia. Faltan estudios como para entender cómo fue la recepción del criollismo popular entre ellas, pero todo indica que fue una empresa abrumadoramente masculina. Entre los autores de historias de matreros las mujeres están conspicuamente ausentes. Por lo demás, en las historias de gauchos las mujeres, o bien no tienen voz en absoluto -como la omnipresente "china" que los acompaña-, o bien aparecen como objeto de disputa entre los varones que llevan adelante la trama. La tensión entre el criollo y sus adversarios -la autoridad, el estanciero o el inmigrante- con frecuencia se tramita narrativamente como una lucha por la apropiación de alguna mujer. Sólo en un caso, de autor incierto, una mujer aparece conduciendo un relato (Manso, s/ f; Aprile, $s / f$ )

Que la libertad utópica de los gauchos era cosa de varones quedaba claro además en la tensión homoerótica que envolvía las amistades más famosas del género. Fierro refiere a su "china” con tal displicencia que ni el nombre sabemos. Pero su amistad a primera vista con Cruz, su decisión de exiliarse juntos, su convivencia bajo un mismo toldo, la ternura con la que lo cuidó al enfermarse y el dolor lacerante que sufrió al verlo muerto están descritos en detalle y en tonos melodramáticos. Y sabemos que Moreira y Julián, al reencontrarse ya como fugitivos, "se besaron en la boca como dos amantes, sellando con aquel beso apasionado la amistad leal y sincera que se habían profesado desde pequeños” (Gutiérrez, 1961, p. 110). ${ }^{3}$

Por supuesto, la afirmación de la masculinidad por vía del gaucho se hacía a expensas principalmente de las mujeres. Pero la misoginia y la tensión homoerótica se resolvían también en homofobia dirigida contra otros grupos, especialmente los inmigrantes. En el Martin Fierro, por caso, su virilidad queda puesta en duda (“...solo son güenos/pa vivir entre maricas”), algo que se repite en otras obras (Discepolo, 1926). En esto el criollismo popular coincidía con el nativismo de orientación más elitista como el de Leopoldo Lugones, quien también contraponía la altiva libertad del "gaucho viril" a la servidumbre en la que vivía la "chusma 
de la ciudad" (especialmente los inmigrantes) (Lugones, 1961, p. 17). En Argentina, como en todas partes, las ideologías nacionalistas tendieron a postular a los varones como encarnación privilegiada de la nación. Sin embargo, en otros puntos las coincidencias se acababan. El criollismo popular reclamó la masculinidad del gaucho como ariete contra otros adversarios, como los ricos o los letrados (algo que Lugones no habría apreciado). En la primera parte del Martín Fierro la falta de hombría de los gringos los vuelve similares no sólo a los "maricas” sino también a los jóvenes de clase alta (“...en lo delicaos/parecen hijos de rico”). Y como otro prolífico autor de cuadernillos gauchescos le hizo decir a uno de sus héroes ficcionales, "Los gauchos tenemos alma/ aunque algunos dotorcitos,/ de esos abotonaditos/ lo mesmo que una mujer/ nos suelen aborrecer/ y hasta nos tienen proscritos" (Rolleri, 1900, p. 9).

En ese sentido, el rasgo más destacado de la vida de los matreros -su valor y su destreza en la pelea cuerpo a cuerpo- podía funcionar como un código de valor alternativo al que proponía el orden social imperante. Si estaba claro que un varón de clase acomodada era más que un pobre por el dinero que poseía, por su poder político o por su cultura, en el terreno de la pelea cuerpo a cuerpo la jerarquía podía revertirse. Un pobre podía ser "más hombre" que un rico: otro motivo más para identificarse con el héroe gaucho violento y cuchillero (sea imaginariamente a través de la literatura, o también en la pretensión de actuar "como un Moreira" en la vida cotidiana). Porque además, hacia fines del siglo XIX la violencia entre varones formaba parte de la vida cotidiana y solía enfrentar a jóvenes de clase baja con esas "patotas" que formaban los hijos de familias de la élite, que por esos años se vieron poderosamente seducidos por la cultura popular. En los tugurios y prostíbulos de las orillas en los que comenzaron a aventurarse para aprender a bailar tango y para alternar con mujeres de clase baja, no pocas veces intentaron probar su hombría provocando peleas con los varones de baja condición (Montaldo, 2016, pp. 193-212).

Por todo esto, las visiones nostálgicas y las críticas que planteaba la literatura del criollismo popular estaban lejos de ser un mero invento de escritores urbanos: conectaban bien con la experiencia y con las percepciones de los paisanos que fueron sus primeros lectores. Y aunque los cambios en años posteriores fueron dramáticos, la nostalgia por tiempos pasados no tenía por qué desaparecer junto con ellos. Si nos paramos imaginariamente en algún paraje bonaerense de 1925, encontraremos allí, ya ancianos, a algunos de los que habían sido mozos en el mundo de 1876. Sus hijos y sus nietos seguramente habrían escuchado de sus bocas las descripciones del campo de antaño, de modo que, al leer folletos criollistas, también podían identificarse con la suerte de los héroes matreros. El atractivo de las proezas de los gauchos en su lucha contra la autoridad podía ser, para los habitantes del campo, una rebelión (que ya no era posible dar en el plano real y que por eso se transfería al plano imaginario) contra una orden social y contra una deriva histórica que no podían sentir justos.

Pero el atractivo del criollismo popular fue igualmente poderoso entre las clases trabajadoras urbanas, cuya realidad era bien diferente. Por supuesto, había también allí gente que había crecido en el campo. En la segundo mitad del siglo XIX y durante buena parte del siguiente las principales ciudades de la región pampeana recibieron un importante contingente de migrantes internos procedentes de zonas rurales. Buenos Aires hospedó una gran cantidad, al principio llegados especialmente del interior bonaerense y del litoral, y desde los años treinta también de más lejos. Un viajero español tuvo la ocasión de hablar con uno de ellos en tiempos del Centenario. Mientras viajaba en tren interiorizándose de la literatura nacional con una copia del Martín Fierro en mano, un anciano con vestimenta urbana se le acercó. Le dijo que de joven había sido un gaucho, que vestía chiripá y galopaba libre por las llanuras, antes de que las estropearan los gringos con sus arados y sus máquinas para sacarle ganancias para ellos y para los estancieros. Y continuó con los ojos llenos de lágrimas viendo el campo por las ventanas: 


\section{LA CIUDAD Y LOS INMIGRANTES}

Pero sabemos que personas de los más diversos orígenes consumieron con entusiasmo las historias de gauchos matreros. A pesar de los elementos xenofóbicos que contenían, también los gringos sucumbieron ante su atractivo. Más aún, los italianos y españoles tuvieron un papel bastante central en el fenómeno del criollismo popular. Casi todos los editores de cuadernillos gauchescos eran de ese origen, y una porción relevante de los escritores también. Eran italianos o descendientes de italianos buena parte de los empresarios teatrales y de los dueños de circos en los que se representaban dramas gauchescos. También eran apellidos italianos los que se destacaban entre los fundadores de círculos criollos. Y, por supuesto, nativos e inmigrantes se mezclaban entre el público lector y espectador ${ }^{4}$. A los italianos que presenciaron el Juan Moreira en el circo de los Podestá no pareció haberles molestado que el "gringo" Sardetti fuera asesinado por el gaucho como parte de la trama. De hecho, luego de una de las primeras representaciones, la Sociedad Opera Italiana de Chivilcoy nombró socios honorarios a los dueños del circo y les regaló una medalla de plata. Y pocos meses más tarde en la ciudad de Santa Fe una compañía de ese origen hizo su propia puesta de esa obra, hablada en italiano (Podestá, 1930, pp. 51 y 72; ver tb. Zubillaga, 1998). ¿Qué atractivo encontraban en las historias de matreros todas estas personas que no tenían conexiones propias con el mundo rural ni memorias del pasado criollo?

Para empezar, los inmigrantes que participaban del criollismo popular no eran sólo extranjeros, sino también varones y mayoritariamente de condición trabajadora, por lo que compartían los motivos de género y de clase que explican el interés de los nativos. Pero además, para los recién llegados empaparse de la cultura gauchesca, valorar el mundo criollo, adoptar expresiones del habla rural, tomar mate y comer asado, tocar la guitarra, vestirse a la manera de los paisanos (o disfrazarse de Moreira en carnaval, algo muy popular por entonces) eran modos de integrarse a la comunidad local. Como emblema de autenticidad, el del gaucho era bastante inclusivo y fácilmente "apropiable". Sus supuestos atributos morales no eran demasiado controversiales: cualquiera podía valorar positivamente el coraje, el desinterés, la nobleza de espíritu, la lealtad con los amigos, el deseo de libertad. Además, para ser un "criollo de ley” no hacía falta provenir de ningún grupo étnico en particular. No se exigía ninguna pureza de sangre, ninguna antigüedad en la tierra. La propia sociabilidad rural había sido desde siempre muy inclusiva: ese territorio nuevo que fue la llanura pampeana había recibido desde tiempos de la colonia gente de muchos lugares. El mestizaje biológico y cultural fue allí una realidad desde el comienzo. Ser un gaucho implicaba apenas compartir cierto estilo de vida, manejar saberes ecuestres y lucir como gaucho. Incluso los inmigrantes de la última oleada pudieron presentarse como "gauchos" a poco de vivir aquí. Como observaron las autoridades ya desde la década de 1870, a veces con asombro y otras con preocupación, por más suizos, alemanes o italianos que fuesen, los inmigrantes que se asentaban en colonias rurales adoptaban costumbres locales con velocidad sorprendente. Hasta los judíos se acriollaron rápidamente y reclamaron el derecho de tener un lugar en la nación como "gauchos judíos". Lo hicieron antes de que Lugones canonizara al Martín Fierro como gran poema nacional; no sólo literariamente a través del célebre libro Los gauchos judios (1910) de Alberto Gerchunoff, sino también previamente en la realidad de la vida en el campo y en la estrecha vinvulación que mantuvieron con los criollos cristianos (salvo en lo religioso) con su estilo de vida (Micheletti, 2010; Gerchunoff, 2010; Freidenberg, 2013; Huberman, 2011)

En la ciudad no era demasiado diferente. Como anotó un escritor de historias de matreros que era hijo de italianos, participar de la cultura gauchesca, "mamar con fruición" las costumbres de la tierra, había permitido a personas como su propio padre "acriollarse" y adquirir "esa misma nobleza del criollo gaucho" de la que hablaban las historias que él mismo escribía, a pesar de haber nacido muy lejos (Aprile, 1936). El propio criollismo, como movimiento cultural, ayudaba a sentirse criollo. Más aún, el propio término criollo funcionó en las primeras décadas del siglo XX como sinónimo de argentino, se tuviera o no ancestros españoles o antigüedad en la tierra. Los editores de la revista Criolla, por ejemplo, reconocían en 1934: "somos todos hijos 
de nobles tanos y gaitas [italianos y gallegos], pero también somos genuinamente criollos hasta la médula de los güesos..." 5 .

Pero además de lo apropiable que era el gaucho como emblema, el propio criollismo popular ayudó a procesar las tensiones del encuentro entre nativos e inmigrantes en más de un modo. Como vimos, las historias de gauchos y otros productos del género solían incluir expresiones de xenofobia. Pero también pueden hallarse manifestaciones en contrario, de aprecio por los recién llegados. Entre los payadores, por caso, no eran extrañas. En la célebre payada que enfrentó a Pablo Vázquez y Gabino Ezeiza en Pergamino en 1894 -cuya transcripción circuló profusamente durante dos décadas-, ambos cantaron loas a los inmigrantes por colaborar con el progreso local y echaron votos por la fraternidad de nacionales y extranjeros. En otra composición Ezeiza también bendijo la unión que se estaba produciendo entre unos y otros y las mismas ideas repitieron otros colegas suyos con posterioridad ( Contrapunto..., s/f, pp. 91-95; Ezeiza, 1897, pp. 51-53; Castro, s/f, pp. 48-49; Barrios, 1948a ; Barrios, 1848b, p. 62). El teatro de temática gauchesca abordó insistentemente la tensión entre criollos e inmigrantes, habitualmente de manera benevolente hacia los segundos. En Solané(1872) el gaucho protagonista tenía palabras afectuosas hacia los “italianitos" que venían a ofrecer su trabajo y manifestaba su deseo de que en el futuro "mezclaran su polen" para generar, junto a los criollos, "una nueva raza”. En Gauchos y gringos de Justo López de Gomara (1884) hay ideas semejantes, y en obras posteriores fueron comunes las tramas en las que la tensión entre gauchos e inmigrantes hallaba alguna síntesis feliz a pesar de sus diferencias (Fernández, 1926, p. 304; López de Gomara, 1963; Novión, s/f; Sanchez, s/f; Vaccarezza, 1926; Discepolo, 1926; Montiel, 1931; Piratte, 1921. Ver tbPellettieri, 1999). De este modo, el teatro se las arreglaba para dar voz a los sentimientos antigringos y para ofrecer, al mismo tiempo, un horizonte de integración.

Pero acaso lo más importante de todo es que el criollismo popular alumbró a Cocoliche, uno de los personajes más perdurables de la cultura argentina, que encarnó a esos gringos que se apropiaban del emblema gauchesco en el tránsito hacia su integración. La historia es conocida. El personaje nació en 1890 en el circo de los Podestá de un modo totalmente casual. Una noche, bromeando con Antonio Cocoliche, un peón calabrés de la compañía, que hablaba muy mal el castellano, lo hicieron participar en la fiesta que se ponía en escena como parte del Juan Moreira. En el circo la improvisación era la regla y José Podestá estaba siempre atento a las respuestas del público. Vivía de los boletos que pagaban los espectadores, así que lo que gustaba, quedaba. Y como el público festejó las pocas palabras que dijo, poco después el elenco de la obra pasó a incluir un actor profesional que se ocupaba de representar el papel que el pobre calabrés había "descubierto". Se aparecía en escena montando un caballo pésimo, vestido al estilo gaucho pero de manera estrafalaria, y decía sus parlamentos en un dialecto que se escuchaba como el de un italiano llegado hace poco que estuviese intentando pasar por gaucho. Doble simulación: el actor a cargo del papel era Celestino Petray, un criollo que actuaba imitando el habla de un italiano que trataba de sonar como un gaucho. Había nacido Cocoliche, el tano que presumía de ser un "criollo de ley" y que generó carcajadas en varias generaciones de argentinos (Podestá, 1930, p. 63).

Si la oralidad popular fue la fuente de ambos, Cocoliche recorrió un camino inverso al de las historias de matreros, pasando del circo a los impresos baratos. Más aún: dio lugar a un nuevo estilo de habla plebeya, también llamado cocoliche, que plasmó el proceso de hibridación cultural que estaba aconteciendo en el bajo pueblo. Un contemporáneo lo describía como "una mezcla de los dialectos genovés y napolitano con el gauchesco y compadrito" (Quesada, 1902, p. 53). Las composiciones en ese dialecto fueron muy habituales en el circuito de escritores y editores de historias de matreros. Dos de sus autores más prolíficos, Manuel Cientofante y Santiago Rolleri, escribieron historias gauchescas versificadas en cocoliche (también lo hicieron en menor medida Silverio Manco y Juan de Nava). Y entre los impresos baratos del género circularon payadas en ese dialecto y transcripciones de las actuaciones del personaje circense que le dio origen (Estroface, 1901; Canciones del napolitano..., 1899; Payadas de contrapunto..., s/f; Vargas, 1902; Cientofante, 1902; Cientofante, 1900; Cientofante, 1901; Rolleri, s/f a; Rolleri, s/f b; Manco, s/f; Las peripecias..., s/f; Nava, 
1899; Profesor Ortega, 1900). La mixtura entre el criollismo y el habla cocoliche generó consternación entre quienes esperaban que el emblema gaucho pudiera ser anclaje para una nacionalidad concebida justamente como defensa frente a la "descaracterización" de la cultura local por efecto del aluvión inmigratorio. Se suponía que el gaucho y el gringo eran figuras antagónicas, pero la cultura popular las había hibridado.

Cocoliche tuvo una larga trayectoria en los picaderos del circo de los Podestá y de muchos otros y pasó a los tablados del teatro, a la literatura, al cine, a la radio y a la prensa gráfica. En la radio de los años treinta le sacó provecho, por caso, el humorista que se hacía llamar Scangárielo. ${ }^{6}$ Y fue infaltable compañero del gaucho de carnavales, para desagrado de los tradicionalistas; algunos de los centros criollos de comienzos del siglo, de hecho, desfilaban con sus atuendos gauchos en esa celebración, liderados por sus Cocoliches (Seigel, 2000). Trascendió además el ámbito gauchesco y fue retomado como personaje urbano, siempre como objeto de hilaridad. Algunos tangos tempranos de Ángel Villoldo se cantaban en cocoliche y el teatro explotó esa vena en innumerables piezas. Celestino Petray interpretó uno de estos cocolichescos habitantes de la ciudad en el exitoso film mudo Nobleza gaucha, y Tomás Simari hizo lo propio en la radio en los años treinta con su detective Nick Vermicelli, por nombrar sólo algunos ejemplos.

Aunque algunos estudiosos interpretaron la figura de Cocoliche como una expresión de xenofobia, la mayoría coincide en que, lejos de eso, la risa que generaba servía más bien para liberar tensiones y como modo de aceptar a los inmigrantes a través de una burla humorística que, más que agredirlos, los incluía. Ni gaucho cabal ni ya un italiano de Italia, ni totalmente argentino ni del todo extranjero, en su propia indefinición Cocoliche le otorgaba un lugar al gringo (al menos al que estaba decidido a integrarse) en la escenificación del mundo gaucho que funcionaba como representación privilegiada del "nosotros" popular argentino. Ya no era ese extranjero irritante que despreciaba Martín Fierro: no había concluido del todo su acriollamiento, pero ya era uno de nosotros (Seigel, 2000; Cara-Walker, 1987). En el espacio afectuoso que abrió para este personaje, el criollismo popular se separaba así claramente de la xenofobia de los nacionalistas del estilo de Lugones.

Para empezar, los inmigrantes que participaban del criollismo popular no eran sólo extranjeros, sino también varones y mayoritariamente de condición trabajadora, por lo que compartían los motivos de género y de clase que explican el interés de los nativos. Pero además, para los recién llegados empaparse de la cultura gauchesca, valorar el mundo criollo, adoptar expresiones del habla rural, tomar mate y comer asado, tocar la guitarra, vestirse a la manera de los paisanos (o disfrazarse de Moreira en carnaval, algo muy popular por entonces) eran modos de integrarse a la comunidad local. Como emblema de autenticidad, el del gaucho era bastante inclusivo y fácilmente "apropiable". Sus supuestos atributos morales no eran demasiado controversiales: cualquiera podía valorar positivamente el coraje, el desinterés, la nobleza de espíritu, la lealtad con los amigos, el deseo de libertad. Además, para ser un "criollo de ley" no hacía falta provenir de ningún grupo étnico en particular. No se exigía ninguna pureza de sangre, ninguna antigüedad en la tierra. La propia sociabilidad rural había sido desde siempre muy inclusiva: ese territorio nuevo que fue la llanura pampeana había recibido desde tiempos de la colonia gente de muchos lugares. El mestizaje biológico y cultural fue allí una realidad desde el comienzo. Ser un gaucho implicaba apenas compartir cierto estilo de vida, manejar saberes ecuestres y lucir como gaucho. Incluso los inmigrantes de la última oleada pudieron presentarse como "gauchos" a poco de vivir aquí. Como observaron las autoridades ya desde la década de 1870, a veces con asombro y otras con preocupación, por más suizos, alemanes o italianos que fuesen, los inmigrantes que se asentaban en colonias rurales adoptaban costumbres locales con velocidad sorprendente. Hasta los judíos se acriollaron rápidamente y reclamaron el derecho de tener un lugar en la nación como "gauchos judíos". Lo hicieron antes de que Lugones canonizara al Martín Fierro como gran poema nacional; no sólo literariamente a través del célebre libro Los gauchos judios (1910) de Alberto Gerchunoff, sino también previamente en la realidad de la vida en el campo y en la estrecha vinvulación que mantuvieron con los criollos cristianos y (salvo en lo religioso) con su estilo de vida (Micheletti, 2010; Gerchunoff, 1910; Freidenberg, 2013; Huberman, 2011) 


\section{EL CRIOLLISMO Y LA ASUNCIÓN (REAL O VICARIA) DE LO NEGRO Y LO MESTIZO}

Como sostuve en otra parte, el criollismo con mucha frecuencia reponía la presencia de lo mestizo y de lo afroargentino como parte del mundo popular y, por ello, implícitamente, como parte de la nación. Los gauchos negros y mestizos, o descritos como de pieles morenas o próximos al mundo de los indígenas, fueron muy abundantes desde el comienzo hasta el final del fenómeno. En ese punto, el criollismo generaba interferencias en los discursos oficiales de la nación que promovía el Estado a través del sistema escolar, y que la mayor parte del campo intelectual hacía propios: aquellos que sostenían que el pueblo argentino era étnicamente europeo (y no mestizo, como el resto de América Latina) y de "raza blanca". De hecho, es posible que, así como servía para procesar las tensiones entre gringos y nativos, el criollismo también sirviese para canalizar las que surgían de los atributos "raciales" disímiles entre los argentinos, en un contexto cultural que estigmatizaba e invisibilizaba a los de ancestría no exclusivamente europea y de fenotipo no-blanco (Adamovsky, 2014)

No hay suficientes estudios que permitan saber cómo se relacionaban los habitantes de origen indígena o africano con el criollismo, pero varios indicios permiten suponer que también ellos encontraron que tenía resonancias con su experiencia de vida. Obviamente, esto aplica para los paisanos del campo de origen africano, que no eran pocos, y que podían compartir los mismos motivos que sus vecinos blancos para verse atraídos por las historias gauchescas. Por otra parte, en la ciudad la comunidad afroporteña participó activamente en la difusión del criollismo, como consumidora y como productora. Entre los quince autores más prolíficos del criollismo popular del cambio de siglo al menos dos eran negros ${ }^{7}$. Los tres mejores exponentes del arte de la payada fueron afroargentinos (a los que habría que agregar unos cuantos más, menos conocidos) (Román, 1953). A fines de siglo, Gabino Ezeiza aprovechaba sus canciones para presentarse como parte "de la raza de Falucho", la de los que "fueron esclavos" y que contribuyó decisivamente a la lucha por la Independencia (algo que también resaltaba su colega Higinio Cazón) (Lewis, 1996, pp. $76-77$ y 119-120; Cazón, s/f). El conjunto musical que conformaron hacia 1915 el famoso guitarrista Oscar Alemán con sus hermanos y su padre se llamó Sexteto Moreira y actuaba en atuendo gauchesco. Los jóvenes Alemán eran de tez marcadamente oscura, al punto que Oscar -que en verdad sólo tenía noticias de ser descendiente de indígenas- sospechaba la existencia de algún antepasado africano reciente y se presentaba él mismo como "negro" (Karush, 2017, pp. 15-20). Y existe evidencia de que personas de ese origen participaron activamente en algunas de las primeras puestas en escena gauchescas animadas por entidades tradicionalistas. Entre las fotografías de la "gran fiesta criolla" que el Museo Colonial organizó en Luján en noviembre de 1931 se distinguen al menos dos de ellos, incluyendo una muchacha montando a caballo como parte de un grupo de gauchos ${ }^{8}$.

De manera algo menos evidente, también las experiencias de vida de las personas de ascendencia amerindia pudieron hacerlas partícipes del criollismo. Para empezar, indios y paisanos no formaban dos conjuntos claramente delimitados, o al menos no siempre. Sabemos, por caso, que desde antes de la llamada Campaña al Desierto algunos ranqueles vestían como gauchos y usaban el término gaucho en sentido elogioso cuando querían decir que una persona era fuerte y valiente (sea que fuese blanca o ranquel). Reconocían además que había lo que ellos llamaban indios gauchos, que no vivían ni entre los cristianos ni en las tolderías, sino en ese espacio poroso y mestizado que era la frontera. A comienzos del siglo XX un estudioso notó algo similar entre los habitantes originarios del Chaco: algunos vestían "como gauchos" y conocían las hazañas de Juan Moreira (Mansilla, 1966, pp. I, 93, 138, 154, 209, 274, 292; II, 68, 119, 125, 171, 198, 235, 263; Bialet Massé, 1986, pp. I, 60, 90, 101, 75). Además, desde muy temprano hubieron indígenas que eligieron identificarse como "criollos" cuando optaban por el camino de la integración a la sociedad argentina. La utilización de una fachada pública de "criollo" o "paisano" fue documentada entre personas de ascendencia huarpe, mapuche y ranquel; entre estos últimos, una investigadora notó también el gusto por los productos culturales criollistas (Escolar, 2007, pp. 72 y 77; Delrio, 2005, p. 67; De Jong, 2000; Salomón Tarquini, 2010, p. 132). 
Pero más allá de los vínculos de afroargentinos, indígenas o mestizos con el criollismo, puede que hubiera habido también un interés por mostrar la relación entre lo gauchesco y lo no-blanco por parte de personas que no pertenecían a grupos étnicos minoritarios ni tenían tez amarronada. Uno de los terrenos en los que esta posibilidad mejor se evidenció fue el carnaval: nada mejor que un ritual de inversión para cuestionar la jerarquía implícita de los colores y para mostrar la heterogeneidad étnica de la nación. Esto se dio de diversas maneras, pero en lo que respecta específicamente al criollismo de carnaval, un observador de la celebración porteña de 1923 registró que algunos de los que salían disfrazados de gauchos se tiznaban la cara como parte del disfraz (Duro, 1923, p. 28). Una foto de una murga de motivos gauchescos tomada en Berisso en 1935 lo confirma (lo mismo que otra de un conjunto de gauchos del Centro Tradicionalista de Valentín Alsina, en el que algunos iban con la cara embetunada y un óvalo blanco en la boca, forma habitual de representar a los negros) ${ }^{9}$. Por otro lado, la evocación del mundo criollo a veces incluía la presencia de afroargentinos. En el concurso de máscaras que organizó Radio del Pueblo en Buenos Aires en 1934, por ejemplo, se presentó un dúo de jóvenes que payaba a contrapunto, uno personificando a un "negrito ladino" y otro a un gringo "cocoliche" 10 . El carnaval también ofreció abundantes ocasiones para la presentificación de los indígenas, combinándose en ocasiones con los disfraces de gauchos (Pérez Bugallo, 1992) ${ }^{11}$.

Así, de múltiples maneras la cultura local encontró en el criollismo un canal para tematizar, de manera implícita, la heterogeneidad étnica del pueblo argentino y la variedad de sus fenotipos. Contar historias acerca del mundo gaucho o representarlo visualmente ofrecía un marco seguro para hacer presente la variedad étnico-racial de la nación, en un contexto cultural que más bien tendía a negarla. Desde el criollismo se proponía a lo criollo/gauchesco como corazón de la autenticidad popular y de la nacionalidad. Pero dados los sentidos étnicos asociados (o asociables) a lo gaucho, que venían sedimentados desde períodos anteriores -lo mestizo, lo moreno-, también ofrecía la posibilidad de minar sutilmente los discursos blanqueadores que, o bien despreciaban todo lo que fuese criollo, o bien lo aceptaban como una presencia meramente "espiritual" o conectada exclusivamente con la estirpe hispánica.

\section{La construcción de un Pueblo}

Que se separara de ese nacionalismo excluyente, sin embargo, no significa que el criollismo popular no tuviese relación con la cuestión que desvelaba a los nacionalistas: la de dotar de alguna cohesión a esa sociedad desordenada y magmática que era la Argentina del cambio de siglo. A su modo, el criollismo popular también participó de esa búsqueda, aunque desde un punto de vista diferente al que tenían las élites intelectuales. En parte, su atractivo se explica justamente porque conectaba con una búsqueda de la propia sociedad, que necesitaba asentar sus vínculos en algún sentimiento de pertenencia colectiva. Pero las visiones de ese "nosotros" que era preciso construir podían ser muy disímiles. Las élites y el Estado proponían las suyas y en esa búsqueda, se vieron forzadas a aceptar la figura del gaucho como emblema insoslayable.

Pero las clases populares -en sus producciones culturales tanto como a través del consumo- también aportaban respuestas propias a la pregunta por el "nosotros". O, dicho en otras palabras, formaban parte central de un proceso de etnogénesis en curso. El concepto de etnogénesis suele ser utilizado por los antropólogos para describir ciertas dinámicas de los grupos étnicos, como su formación, la fusión de dos o más, la absorción de uno por otro, en fin, los diversos caminos por los que se crea un ethnos o, en términos más sencillos, un pueblo con una identidad definida. También los historiadores lo han encontrado útil, especialmente para entender la formación y la trasformación de las naciones a través del tiempo. Porque también las naciones se forman y transforman trazando límites entre un "nosotros" y los otros, abrazando nombres y símbolos visuales que las definen y construyendo narrativas que expliquen sus orígenes y su itinerario a través del tiempo. También las naciones deben definir su perfil étnico, que no es otra cosa que 
responder a la pregunta sobre el origen, el aspecto y las cualidades (reales o imaginarias) de los cuerpos humanos que las conforman (Smith, 2009).

Un estudioso de la cultura popular de esa época sostuvo justamente que el atractivo del criollismo radicaba en su capacidad de "articular" los diversos segmentos que conformaban las heterogéneas clases populares del cambio de siglo. No fue tanto (o sólo) una expresión cultural que daba sentido a la experiencia de vida de sujetos preexistentes - los paisanos en el campo, los criollos en la ciudad, los inmigrantes, los afroargentinos, los mestizos- como una práctica cultural novedosa que permitió producir un "pueblo" donde antes no existía. Pueblo, desde este punto de vista, es un sujeto político que llega a imaginarse como un todo unificado a partir de su común oposición al mundo de las élites. Es a partir de la diferenciación con ese mundo que los diversos segmentos se articularon entre sí y construyeron un sentido de unidad. Y en esa construcción el criollismo popular tuvo un papel crucial, porque ofreció a cada quien un modo atractivo de representar a ese "nosotros" en formación, y de identificarse con esa representación. En un contexto de triunfo de las clases altas que implicó no sólo una mayor desigualdad sino también la exclusión política de las clases populares y la imposición de una cultura, una estética y valores liberales, europeizantes y blanqueadores, la "estrategia representacional" que fue el criollismo -identificarse con el héroe matrero, disfrazarse de Moreira, imitar el habla del gaucho, simular su autenticidad rústica, actuar sus insumisiones, su coraje brutal y su reclamo de justicia, tiznarse la cara, o rememorar lo africano o lo indígena- tenía una dimensión antagónica evidente. $\mathrm{Al}$ representarse como pueblo (auténtico) a partir de esas características y esas memorias, la multitud así articulada se afirmaba precisamente en el legado de "barbarie" criolla que las élites venían intentando extirpar. Esta estrategia representacional tenía sentido no tanto como expresión de los sujetos propios de la sociedad anterior a la gran inmigración, como por su valor a la hora de recortar un mundo popular en oposición a los proyectos político-culturales de la élite gobernante. En ese sentido, que las personas que participaran en ella tuvieran o no piel amarronada o un vínculo directo, "real", con el pasado criollo era lo de menos. ${ }^{12}$

El sujeto popular que podía imaginarse como un "nosotros" a través del emblema gaucho se reclamaba, así, auténticamente local. En ese punto coincidía con las operaciones culturales que intentaba un intelectual como Lugones, cuando de manera tardía buscó apropiarse del Martín Fierro para un programa nacionalista. En la afirmación de la masculinidad como viga dominante de la comunidad también convergían. Sin embargo, las diferencias entre las visiones de la nación que surgían de ambas empresas eran muy grandes. El "nosotros" que el criollismo popular proyectaba era plebeyo e insumiso y hacía un lugar al componente extranjero todavía mal integrado (siempre y cuando tuviese intención de acriollarse, claro). Y, sobre todo, se relacionaba mal con las clases altas.

Puesto a recordar su infancia muchos años más tarde, uno de los tantos hijos de los inmigrantes que llegaron a comienzos del siglo XX dejó bien graficada esa diferencia. En su caso, era hijo varón de una familia de judíos pobres que se habían establecido en un barrio obrero de la ciudad de Buenos Aires. Siendo niño en la década de 1920, recuerda, salía en los carnavales, como se acostumbraba entonces, en pandilla con otros niños del barrio de diversos orígenes étnicos. Más allá de sus diferencias, los unía su condición de clase, que para ellos se expresaba en la antipatía que sentían por los niños de familias "bien", cuya hombría, ya a esa edad, habían aprendido a poner en duda. Con la murga del barrio cantaban: "¡Aquí viene Juan Moreira,/ con su poncho y su cuchilla!/ ¡Retirate cajetilla,/ que te rompo las costillas!"(Serta, 1965, p. 114). Al identificarse con el gaucho legendario, con su valor puesto ahora a enfrentar a los ricos -algo que en verdad el personaje de Gutiérrez nunca había hecho-, ese niño judío y pobre, junto a sus amigos, podía reclamar una pertenencia al "nosotros" (popular) argentino.

\section{Criollismo popular y POLÍtica}

Los elementos de crítica social que acabamos de reseñar marcan diferencias cruciales entre el criollismo popular y el tradicionalismo nacionalista de un Lugones, o de las asociaciones gauchescas de la década de 
1930. Entre estos no era habitual que se plantearan críticas a la ley o la autoridad (ni mucho menos que se exaltara la violencia). Tampoco que hubieran invectivas contra la desigualdad que incluyeran las diferencias entre ricos y pobres. Inversamente, la ansiedad por la descaracterización nacional no solía ser tema central para los autores del criollismo popular. Tampoco se planteaba ninguna cercanía entre el gaucho y la Iglesia o siquiera la religiosidad (salvo en alguna medida en el Martín Fierro). El punto de mayor contacto parecía ser la hostilidad a los gringos, pero, como vimos, su tenor era bastante diferente.

Que el perfil político del criollismo popular estaba lejos del de un nacionalismo de derechas queda además claro al considerar las militancias o simpatías partidarias que tuvieron varios de sus principales cultores, que fueron en general claramente democráticas, antielitistas o incluso izquierdistas. En efecto, varios de los autores más prolíficos -como Manuel Cientofante o los payadores Higinio Cazón y Pablo Vásquez- apoyaron explícitamente a Leandro Alem, fundador de la Unión Cívica Radical. Otros posteriores, como Ramón Aguirre y Ambrosio Río o los famosos payadores José Betinoti y Félix Hidalgo, también se identificaron con la UCR. El más grande de los payadores, Gabino Ezeiza, fue un destacado militante de ese partido, al que dedicó varias composiciones y en cuyos actos solía cantar. El más prolífico de todos los escritores del género, Silverio Manco, tuvo simpatías inicialmente socialistas o anarquistas y luego se volcó al radicalismo (colaboró en periódicos de orientación yrigoyenista), sin dejar de predicar ideas obreristas. Entre los payadores de fama en las primeras décadas del nuevo siglo, Evaristo Barrios fue socialista, mientras que el renombrado Martín Castro era militante anarquista (su colega Luis Acosta García también era de ideas libertarias). Y entre los compositores folklóricos que retomaron las tradiciones pampeanas y la figura del gaucho perseguido, los dos más importantes respondían a un perfil similar: Buenaventura Luna fue militante del bloquismo sanjuanino, mientras que Atahualpa Yupanqui lo fue del Partido Comunista. Más aún: ambos utilizaron la figura del gaucho o referencias al Martín Fierro para denunciar los padecimientos que sufrían los trabajadores criollos de la actualidad. Contrariamente, ninguna de las personas que animaron el fenómeno del criollismo popular en todos esos años -al menos de las que he podido hallar datos personales- sostuvo lealtades derechistas (con la excepción del rosarino Francisco N. Bianco, que en los años treinta manifestó cierta simpatía por los conservadores) ${ }^{13}$.

Además, ocasionalmente los cuadernillos de historias gauchescas podían incluir versos explícitamente anticapitalistas. El Martín Fierro que publicó reversionado el editor Andrés Pérez en el cambio de siglo incluía la letra completa de "Hijos del pueblo", el himno anarquista que llamaba a los proletarios a luchar contra la burguesía (Cientofante, s/f, p. 31). Y no era extraño que los payadores de orientación socialista o anarquista publicaran sus composiciones intercalando temas gauchescos con versos de contenido anticapitalista (Arcidiácono, 1903; Manco, s/fb; Acosta García et al., 1933)

Inversamente, las organizaciones políticas de izquierda y del movimiento obrero hicieron un uso muy temprano del criollismo como canal para difundir las ideas revolucionarias. Así como los cuadernillos gauchescos podían incluir himnos políticos, también los cancioneros izquierdistas del cambio de siglo traían a veces milongas compuestas por "payadores gauchos" anarquistas o socialistas ( El cancionero revolucionario..., 1905, pp. 38-39; Cancionero Socialista..., s/f, pp. 11-15). Los anarquistas fueron los que más explotaron el potencial político del emblema gaucho. Ya en 1899 Eduardo Gilimón, un militante nacido en España que estuvo entre los fundadores de La Protesta, el principal periódico de esa corriente en Argentina, aprovechó para resaltar el costado subversivo de las historias de matreros. En algunos de sus textos de ese año explicó a los "paisanos" que el "progreso" significaba un empeoramiento de sus vidas por culpa del Estado, de los comerciantes y de los ricos. Los "gauchos argentinos" fueron parias perseguidos, comparables por ello a los anarquistas; "las rebeldías a lo Moreira" fueron "el fugaz destello de libertad que antes brillaba en el criollo" 14 . Desde esta analogía, los anarquistas intentaron apropiarse del Martín Fierro una década antes de que lo hiciera Lugones. En 1904 Alberto Ghiraldo, uno de los jóvenes intelectuales más destacados de esa corriente, fundó una revista político-cultural a la que bautizó, justamente, Martín Fierro. Así se explicaba la elección del nombre en el número de presentación: 
Martín Fierro es el símbolo de una época de nuestra vida, la encarnación de nuestras costumbres, instituciones, creencias, vicios y virtudes, es el grito de una clase luchando contra las capas superiores de la sociedad que la oprimen, es la protesta contra la injusticia, es el reto varonil e irónico contra los que pretenden legislar y gobernar sin conocer las necesidades de los que producen y sufren, es el cuadro vivo, palpitante, natural, estereotípico de la vida de un pueblo ${ }^{15}$.

Poco después de su aparición y hasta que la represión le puso fin en 1905, la revista se transformó en el suplemento cultural de La Protesta, de modo que llegó ampliamente a los trabajadores anarquistas. Abundaron en sus páginas los textos criollistas, con dos secciones fijas dedicadas a hablar de política en referencia al mundo de los gauchos o a través de su voz. Algunos de los temas propios de ese género venían particularmente bien: obviamente la crítica a la autoridad era propicia para un libertario, pero también el tema de la expansión de los alambrados que acorralaba al gaucho, fácilmente traducible en un cuestionamiento más general a la propiedad privada y al latifundio. La prestigiosa figura del gaucho les permitía anclar en la realidad local el mensaje universal del anarquismo, llegar de manera más atractiva a las clases populares y predicar la solidaridad entre nativos y gringos. Tras el cierre de su revista, Ghiraldo continuó explotando políticamente la figura del gaucho en su obra como dramaturgo, en la que alcanzó bastante éxito (Ansolabehere, 2011, pp. 113-32; Peraldi, 2012).

En los años siguientes la militancia anarquista continuó sacando provecho del criollismo. En ese plan se destacó Juan Crusao (pseudónimo de Luis Woolands), un peón rural nacido en Chascomús en 1885, hijo de padres holandeses. Autodidacta, desde 1914 se acercó al anarquismo y editó materiales libertarios, entre los que se destacó un folleto que tituló Carta gaucha, escrito en prosa y en estilo gauchesco, en el que explicaba a los criollos algunos de los fundamentos del movimiento e insistía en que se mantuviesen unidos con los trabajadores inmigrantes. En el texto, las citas al Martín Fierro se alternaban con ataques a los ricos, a los alambrados y a la autoridad, y llamados a hacer la revolución. Publicado por primera vez posiblemente en 1919, conoció numerosas reimpresiones y se distribuía ampliamente en las ciudades y también en el campo, transportado por trabajadores migrantes y linyeras (Crusao, 1922).

La prensa de los sindicatos controlados por anarquistas también abundó en exaltaciones de la figura del gaucho y en textos criollistas. El periódico gremial de los conductores de carros anunciaba en 1911, por caso, un despertar político de "nuestra raza”, el trabajador criollo, la "raza gaucha" oprimida por la clase alta ${ }^{16}$. La Carta gaucha de Crusao fue reproducida en periódicos de esa orientación numerosas veces, junto con textos de otros autores también en estilo gauchesco ${ }^{17}$. Y posiblemente la prensa anarquista no reflejase cabalmente la importancia que tenía el criollismo en la vida del movimiento. Una investigación sobre Montevideo mostró que los payadores criollos eran parte infaltable de las veladas y los picnics anarquistas de principios del siglo XX. Sin embargo, muy rara vez sus composiciones aparecían en la prensa del movimiento, que prefería en cambio publicar rimas y versos en estilo "culto" (Vidal, 2010). No hay una investigación comparable para ciudades argentinas, pero todo indica que lo mismo aplica para esta orilla del Plata.

Conviene aclarar, sin embargo, que en la tradición izquierdista argentina la valoración positiva del gaucho convivió con una visión contraria, que muchas veces era dominante. Lejos de glorificarlo, algunos sectores del anarquismo y del socialismo consideraron todo lo criollo un factor de atraso político y de conservadurismo. Por caso, en el folleto El crepúsculo de los gauchos (1903) de Félix Basterra, hay virulentas críticas a los gauchos que retoman la dicotomía sarmientina de civilización vs barbarie (Ansolabehere, 2011, p. 106). Así y todo, el criollismo y el emblema gaucho siguieron teniendo un lugar importante entre los izquierdistas de décadas posteriores. El periódico de los comunistas Bandera Roja, por caso, incluyó en 1932 una sección fija llamada "Cartas gauchas", dirigida a paisanos y campesinos, que explicaba en estilo gauchesco la necesidad de unirse a los obreros en la lucha contra el capital ${ }^{18}$. En el plano ensayístico, el escritor comunista Álvaro Yunque publicó en 1941 un influyente estudio sobre la literatura social en Argentina, en el que postulaba que el Martín Fierro había sido una expresión de la lucha de clases en el campo y su autor, un verdadero revolucionario (Yunque, 1941, pp. 122 y 133). 
En fin, los contenidos de crítica social del criollismo popular, su capacidad de hacer lugar al inmigrante, los perfiles políticos de sus cultores, los usos que le dieron las fuerzas de izquierda, y especialmente las visiones del "nosotros" que proyectaba, tal como los hemos analizado en este capítulo ponen en duda la frecuente asociación del emblema del gaucho con las ideologías nacionalistas y de derecha. No es que éstas no lo utilizaran: luego del Centenario lo hicieron de manera intensa. Pero nada autoriza a concluir que los nacionalistas hubiesen tenido el control de sus sentidos. Por el contrario, en la primera mitad del siglo hubo una intensa puja por el significado político del gaucho. Su uso por parte de la derecha se intensificó, pero como emblema continuaba siendo inestable y disputado. La imposibilidad de fijarlo en un sentido derechista se explica naturalmente por el potencial subversivo que tenían las historias de matreros, y por el hecho de que su primera utilización política fue por parte de sectores democráticos o izquierdistas que dejaron sentidos sedimentados difíciles de neutralizar. Por lo demás, el conjunto de los usos que tuvo el criollismo popular sugiere que, más que ser la expresión pasajera de las tensiones de algún proceso de "modernización", fue una de las expresiones culturales que colaboró en el proceso de etnogénesis, es decir, de la conflictiva definición de un sentido de distintividad grupal a partir de la heterogénea población que ocupó el territorio nacional.

\section{ReFERENCIAS}

Aprile, B. R y Sierra, A. (Comp.) (s/f) 1a. Serie de relaciones, zambas, estilos, gatos, vidalitas, cuecas, chacareras, etc. etc., recopiladas y seleccionadas por los tradicionalistas Bartolomé Rodolfo Aprile y Apolinario Sierra. Buenos Aires: Alfredo Angulo.

Abaca, H. (s/f) Paja Brava (poema en verso) (3ra. ed.). Rosario: Alfonso Longo.

Acosta, L. (1939). El gaucho argentino. Buenos Aires: Colecciones Gauchas.

Acosta García, L., Castro, M., Pombo, J. M. y Cepeda, A. (1933). El cantar de los troveros. Buenos Aires: Alfredo Angulo/Colecciones Gauchas.

Adamovsky, E. (2014). La cuarta función del criollismo y las luchas por la definición del origen y el color del ethnos argentino (desde las primeras novelas gauchescas hasta c. 1940). Boletín del Instituto de Historia Argentina y Americana "Dr. Emilio Ravignani"(41), pp. 50-92.

Adamovsky, E. (en prensa). El criollismo popular en Argentina ¿Hasta cuándo? Personajes, autores y editores de un fenómeno de literatura masiva. Cuadernos de Literatura.

Alonso y Trelles, J. (s/f). Paja brava. Buenos Aires: Apolo.

Ansolabehere, P. (2011). Literatura y anarquismo en Argentina (1879-1919). Buenos Aires: Beatriz Viterbo.

Aprile, B. R. (s/f). La gaucha Vicenta. Buenos Aires: Colecciones Gauchas.

Aprile, B. R. (1934). El zorzal argentino. Buenos Aires: El Canta Claro.

Aprile, B. R. (1936). Aparicio Saravia. Buenos Aires: Colecciones Gauchas.

Arcidiácono, J. (1903). Colección de vidalitas. Buenos Aires: s/e.

Barrios, E. (1948a). La guitarra en los fogones. Buenos Aires: Buchieri.

Barrios, E. (1948b). Relatos gauchos y Nuevos relatos gauchos. Buenos Aires: Publicidad Ateneo.

Bialet Massé, J. (1986). Informe sobre el estado de la clase obrera en el interior de la República. 2 volúmenes. Buenos Aires: Hyspamerica.

Blanco, R. J. (2010). El gaucho Lega. Corrientes: Moglia.

Cabrera, F. (s/f). Canciones populares. Buenos Aires.

Cancionero socialista internacional (s/f). s/l.

Canciones del napolitano Cocoliche (1899). Barracas al Sud (sic): La Voz del Comercio.

Cara-Walker, A. (1987). Cocoliche: The Art of Assimilation and Dissimulation among Italians and Argentines.nLatin American Research Review, 22(3) pp. 37-67. 
Casas, M. E. (2017). La metamorfosis del gaucho. Buenos Aires: Prometeo.

Castro, M. (s/f).Versos del pueblo. Buenos Aires: Accinelli.

Cazón, H. D. (s/f). ¡Alegrías y pesares!. Buenos Aires: Maucci.

Chumbita, H. (2011). Jinetes rebeldes. Buenos Aires: Colihue.

Cientofante, M. (s/f) Martín Fierro. Buenos Aires: Andrés Pérez.

Cientofante, M. M. (1900). El gaucho de Cañuelas. Buenos Aires: Salvador Matera.

Cientofante, M. M. (1901). Los amores de Cocoliche con una gallega. Buenos Aires: Salvador Matera.

Cientofante, M. M. (1902). Hermosa colección de dichos criollos. Buenos Aires: Salvador Matera.

Contrapunto entre los famosos payadores Pablo Vázquez y Gabino Ezeiza (s/f). (6ta. ed.). Rosario: Alfonso Longo.

Crusao, J. (1922). Carta Gaucha (5ta. ed.). Buenos Aires: La Protesta.

De Jong, I. (2000). Horizontes compartidos y disputados en la construcción de la identidad indígena: historia y etnicidad en Los Toldos. Histórica XXIV (1) pp. 49-83.

Delrio, W. (2005). Memorias de expropiación. Bernal: UNQ.

Discepolo, A. (1926). Patria Nueva. La Escena (415).

Duro, J. (1923). Un día de carnaval (poema gaucho). Rosario.

El cancionero revolucionario ilustrado (1905). Buenos Aires: Bautista Fueyo.

Escolar, D. (2007). Los dones étnicos de la Nación. Buenos Aires: Prometeo.

Estroface, J. C. (1901). El nuevo libro de canciones napolitanas y criollas. Buenos Aires.

Ezeiza, G. (1897). Nuevas canciones inéditas del payador argentino Gabino Ezeiza. Buenos Aires: Biblioteca Gauchesca.

Fernández, F. (1926). Solané. Buenos Aires: Facultad de Filosofía y Letras.

Fray Mocho (José S. Álvarez) (1910). Tierra de matreros. La Plata: Joaquín Sesé.

Freidenberg, J. (2013). La invención del gaucho judío. Buenos Aires: Prometeo.

Frontera, R. (1999) Chispas gauchescas. Villa Clara: edición del autor.

Garavaglia, J. C. (2001). El Martín Fierro y la vida rural en la campaña de Buenos Aires. En É. Lois y A. Núñez (eds.) Martin Fierro (pp. 654-90). Madrid: Allca XX.

Gerchunoff, A. (1910). Los gauchos judios. La Plata: Joaquín Sesé.

Gutiérrez, E. (s/f). Pastor Luna. Buenos Aires: Tommasi.

Gutiérrez, E. (1880). Santos Vega. Buenos Aires: La Patria Argentina.

Gutiérrez, E. (1961). Juan Moreira. Buenos Aires: EUDEBA.

Hidalgo, F. (1896). Milongas provincianas; verdades de Pedro Grullo; Décimas variadas. Buenos Aires: La Popular.

Hidalgo, S. (1911). Alma gaucha. Buenos Aires: Andrés Pérez.

Huberman, A. (2011). Gauchos and Foreigners. Lanham: Lexington Books.

Karush, M. (2017). Musicians in Transit: Argentina and the Globalization of Popular Music. Durham: Duke University Press.

Lamadrid, F. A. (1905). El gaucho de Cañuelas, segunda parte. Buenos Aires: Biblioteca Gauchesca.

Las peripecias de Franciscone Cocoliche e so moquier Ludonia. (s/f). Rosario: Longo y Argento.

Legrás, H. (2010). Hacia una historia del populismo. En C. Soria; P. Cortés Rocca y E. Dieleke (Eds.). Políticas del sentimiento (pp. 163-180). Buenos Aires: Prometeo.

Lewis, M. A. (1996). Afro-Argentine Discourse. Columbia: University of Missouri Press.

López de Gomara, J. S. (1963). Gauchos y gringos. Buenos Aires: Instituto de Literatura Argentina "Ricardo Rojas".

López Franco, J. (1899). La vida de Juan Macana. Buenos Aires.

Lugones, L. (1961). El payador. Buenos Aires: Centurión.

Mansilla, L. V. (1966). Una excursión a los indios ranqueles, 2 volúmenes. Buenos Aires: Eudeba. 
Manso, S. ( $\mathrm{s} / \mathrm{f}$ a). El Cocoliche, décimas napolitanas criollas para carnaval. Buenos Aires: s/e.

Manso, S. (s/fb). Almas que luchan. Rosario: José Belluccia.

Manso, S. (s/f c). La mujer de Martín Fierro. Buenos Aires: Sabourin e Hijo.

Manso, S. (1943). Venganza gaucha. Buenos Aires: Buchieri.

Micheletti, M. G. (2010). Entre gauchos y gringos. Costumbres nacionales y extranjeras en Santa Fe (1880-1900). Temas de historia argentina y americana (16).

Montaldo, G. (2016). Museo del consumo: archivos de la cultura de masas en Argentina. Buenos Aires: Fondo de Cultura Económica.

Montiel, V. (1931). La bandada rubia. Bambalinas (680)

Nava, J. de (1899). Nueva colección de canciones jocosas y vidalitas. Buenos Aires.

Novión, A. (s/f). ¡Los criollos se han dao... güelta!. En La mejor colección de monólogos cómicos (pp. 4-7). Buenos Aires: El Canta Claro

Payadas de contrapunto para cantar con guitarra (c. 1903). Rosario: Librería Americana de José Belluccia.

Pellettieri, O. (ed.) (1999). Inmigración italiana y teatro argentino. Buenos Aires: Galerna.

Peraldi, C. (2012). Imágenes en conflicto. Las representaciones del pasado rural como instrumento de pugna política al interior del movimiento anarquista argentino, 1900-1910. A contracorriente 10(1) pp. 451-71.

Pérez Bugallo, R. (1992-1993). El carnaval de los 'indios': una advertencia sobre el conflicto social. Cuadernos del Instituto Nacional de Antropología y Pensamiento Latinoamericano (14) pp. 93-120.

Piratte, A. (1921). Quinielas y redoblonas. El Teatro Argentino. pp. 1-24.

Podestá, J. J. (1930). Medio siglo de farándula (memorias). Río de la Plata.

Prieto, A. (2006). El discurso criollista en la formación de la Argentina moderna. Buenos Aires: Siglo veintiuno.

Profesor Ortega (1900). Carnestolendas gauchescas. Buenos Aires.

Quesada, E. (1902). El 'criollismo' en la literatura argentina. Buenos Aires: Coni.

Rolleri, S. (s/f a). La tapera, cantos y vidalitas. Buenos Aires y Montevideo.

Rolleri, S. (s/f b). Nuevas canciones de Cocoliche. Buenos Aires y Montevideo.

Rolleri, S. (1900). El hijo de Martín Fierro (7ma. ed.). Buenos Aires y Montevideo.

Román, M. M. (1953).Los payadores negros. Nativa (360) pp. 20-23.

Rusiñol, S. (1911). Un viaje al Plata. Madrid: V. Prieto y Cía.

Salomón Tarquini, C. (2010). Largas noches en La Pampa. Buenos Aires: Prometeo.

Sanchez, F. (2012). La gringa. Recuperado de http://abajoeltelon.blogspot.com/2007/04/florencio-snchezla-gringa .html

Seigel, M. (2000). Cocoliche's Romp: Fun with Nationalism at Argentina's Carnival. The Drama Review, 44(2) pp. 56-83.

Serta, E. (1965). De mis tiempos de pibe. Buenos Aires: Instituto Amigos del Libro Argentino.

Sierra, A. (s/f). Aparicio Saravia. Buenos Aires: Publicidad Ateneo/Colección Gaucha.

Slatta, R. (1985). Los gauchos y el ocaso de la frontera. Buenos Aires: Sudamericana.

Smith, A. D. (2009). Ethno-symbolism and nationalism: a cultural approach, New York, Routledge.

Vaccarezza, A. (1926). Ya se acabaron los criollos. La Escena (429).

Vargas, M. (1902). Canciones napolitanas y criollas. Buenos Aires.

Vasconcelos, A. (1921). El lonjazo. Buenos Aires.

Vazquez, P. (1901). Lamentos de un payador. Buenos Aires: Biblioteca Gauchesca.

Vida del valiente gaucho oriental Juan Acero (1901). Buenos Aires: Biblioteca Criolla/Salvador Matera.

Vidal, D. (2010). Coplas de realidad y voces proletarias: Los payadores libertarios. Rojo y Negro (9) pp. 18-19.

Yunque, Á. (1941). La literatura social en la Argentina. Buenos Aires: Claridad. 
Zubillaga, C. (1998). Identidad inmigratoria: los gallegos y la literatura gauchesca en el Uruguay de la modernización. Anuario del Centro de Estudios Gallegos (2) pp.191-223. Montevideo.

\section{Notas}

1 Rolleri, 1900: 8; Alonso y Trelles, s/f: 19-21; Vasconcelos, 1921, pp. 57-73; Cabrera, s/f, p. 4; Hidalgo, 1911, pp. 26-32; Lamadrid, 1905, p. 9; 1a. Serie de relaciones, s/f, p. 23; El Canta Claro, no. 553, 17/5/1935, p. 16; Acosta, 1939 , pp. 87-88.

2 Ver tb. Vida del valiente..., 1901, pp.13-14; Vázquez, 1901

3 Varios autores notaron esa tensión, entre otros Ezequiel Martínez Estrada y Josefina Ludmer

4 La fruición con que lo hacían los italianos fue registrada en Quesada, 1902, p. 52

5 Criolla, no. 1,8/11/1934, p. 11

6 "Hoy se casa Scangáriello", Sintonía, no. 129, 12/10/1935, s/p

7 Se trata de Gabino Ezeiza e Higinio Cazón (Prieto, 2006, p. 67)

8 "Una gran fiesta criolla en Luján”, Nativa, no. 95, 30/11/1931, s/p

9 La primera foto pertenece al archivo de Luis Guruciaga; la segunda, al de Mauricio Kartun

10 Sintonía, no. 44, 24/2/1934, s/p.

11 Véanse, para Córdoba, las fotos de comparsas publicadas en La Voz del Interior, 2/2/1951, p. 7; 6/2/1951, p. 5; $7 / 2 / 1951$, p. $7 ; 13 / 2 / 1951$, p. 7

12 Estas ideas (salvo las que refieren al aspecto étnico-racial) están inspiradas Legrás (2010)

13 Las fuentes para la construcción de perfiles políticos están detalladas en Adamovsky, en prensa.

14 Gilimón: “A los paisanos", La protesta humana, 28/5/1899, p. 3; "La langosta", La protesta humana, 26/11/1899, p. 1.

15 Martín Fierro, no. 1, 3/2/1904

16 El Látigo del Carrero, no. 71, 1/12/1911, p. 3

17 Véase por ej. El Carpintero y Aserrador,no. 13, julio 1922 y no. 63, marzo 1926, p. 3. Fuera de Buenos Aires Verbo Nuevo, órgano de la Federación Obrera Provincial Sanjuanina, también abundó en textos de este tipo entre 1927 y 1932.

18 Bandera Roja, no. 1, 1/4/1932, p. 2. 